\title{
SURVEY OF MAIN INSECT SPECIES ASSOCIATED WITH CERTAIN MEDICINAL AND AROMATIC PLANTS AT AWLAD-SAKR DISTRICT, SHARKIA GOVERNORATE
}

\author{
Doaa F. Osman ${ }^{1 *}$, Heba A. Ismail ${ }^{1}$, I.M. Kelany ${ }^{2}$, Shadia M. Omara ${ }^{2}$ and Sh.M. Abd-Allah ${ }^{2}$ \\ 1. Plant Prot. Res. Inst., Agric. Res. Centre, Dokki, Giza, Egypt \\ 2. Plant Prot. Dept., Fac. Agric., Zagazig Univ., Egypt
}

Received: 24/4/2017 ; Accepted: 02/07/2017

\begin{abstract}
The present study was conducted to survey the economic insect pests infesting some medicinal and aromatic plants i.e., roselle (Hibiscus sabdariffa L.), thyme (Thymus vulgaris L.) and sweet basil (Ocimum basilicum L.) and their common associated natural enemies as well as pollinators and visitors at Awlad-Sakr district, Sharkia Governorate, Egypt during the two summer growing seasons 2015 and 2016. The results recorded that 29 insect species belongs to 25 families and 10 orders associated with the three studied medicinal and aromatic plants. Destructive insects comprised 17 species belongs to 15 families and 8 orders. Predaceous insects composed 8 species of 6 families and 5 orders. Parasitoids were represented by only one species on sweet basil. Results also cleared that pollinators and visitors included 3 species belong to 3 families and 2 orders. Aphis gossypii Glover, Bemisia tabaci (Genn.) and Empoasca decipiens (Paoli) were the most dominant insect pests on roselle, thyme and sweet basil plants. A. gossypii was the main insect pest on roselle exhibited by general total percentage of $38.19 \%$ in the two seasons and B. tabaci of $51.40 \%$ on thyme and E. decipiens of $60.48 \%$ on sweet basil. The main predaceous insect recorded on the three aforementioned plants was Coccinella undecimpunctata L., representing 72.53, 56.18 and 30.38\%, respectively. Yellow sticky board trap proved to be the most effective method for collecting E. decipiens, B. tabaci, Thrips tabaci Lind., Musca domestica L., C. undecimpunctata, Metasyrphus corollae (Fabr.), Chelonus ininatus L. and Culiseta longiarolata (Macq.), while the sweeping net was the pest method for collecting Cosmolyce baeticus L., Nezara virdula L., Aphis mellifera L., Philanthus abdelkader Luc. and Egyptica legyptius. Plant sampling technique was effective for estimating A. gossypii and Iceria aegyptiac Douglas.
\end{abstract}

Key words: Survey, destructive insects, parasitoid and predaceous insects, insect pollinators and visitors, plant samples, sweeping net, yellow sticky board trap, roselle, thyme, sweet basil.

\section{INTRODUCTION}

During the last few years, medicinal and aromatic plants attracted more attention and their economic importance increased in Egypt as exported agricultural products for several pharmaceutical and therapeutic purposes. Nowadays, the Government encourages the expansion in cultivation of the medicinal and aromatic plants in Egypt, such as roselle, thyme and sweet basil. Unfortunately, many destructive insect species may feed on these plants until physiological maturation stage and this inevitably leads to eventual loss in the quantity and quality of their products (Afsah, 2005; Banjo et al., 2006). Also, beneficial insects such as, predators, parasitoids, pollinators and visitors can play an important role that affecting productivity of these plants (Ali et al., 2009). A number of investigators have surveyed the

\footnotetext{
*Corresponding author: Tel.: +201097982429

E-mail address: doaakhalil24@gmail.com
} 
insects existing on different medicinal and aromatic plants in Egypt (Ramadan, 1998; Ahmad, 1990; Ali, 1998; Hammad and Mohsen, 2000; Ismail, 2001; Abd El- Megid, 2007; Abd El-Moneim et al., 2011; Ismail et al., 2016). Therefore, the current study aims to survey the insect species associated with roselle, thyme and sweet basil plants such as insect pests, natural enemies, pollinators and visitors.

\section{MATERIALS AND METHODS}

The present work was conducted at AwladSakr district, Sharkia Governorate, Egypt during the two summer growing seasons 2015 and 2016 to survey the insect pests and their associated natural enemies that existed on roselle (Hibiscus sabdariffa L.), thyme (Thymus vulgaris L.) and sweet basil (Ocimum basilicum L.) plants. An area of about $525 \mathrm{~m}^{2}$ was prepared and divided into three equal parts. Each part was divided into three replicates (each about $58 \mathrm{~m}^{2}$ ). The seeds of roselle, thyme and sweet basil plants were sown on the $1^{\text {st }}$ of April in both growing seasons. The experimental area received normal agricultural practices and was not subjected to any chemical control application during the period of investigation

\section{Sampling Techniques}

Three sampling methods were used to survey and count insects inhabiting plants, namely plant sample, insect sweeping net and yellow sticky board trap.

\section{Plant sample}

Weekly samples of 20 leaves from each replicate of roselle and sweet basil plants were collected at random from different levels of plant height. In case of roselle plant, 20 randomized fruits were collected weekly from each replicate during fruiting and boll formation stages and continued to the harvest. While for thyme plant each sample consisted of 20 plants/ replicate (in the seedling stage) and 20 tillers/ replicate (in the vegetative growth stage). All the collected samples were kept in tightly closed paper bags and transferred to the laboratory for examination using a binocular microscope. The stages of insect species inhabited roselle, thyme and sweet basil were counted and recorded. The associated insect natural enemies in the collected samples were classified and counted.

\section{Insect sweeping net}

The insect sweeping net used was $30 \mathrm{~cm}$ in diameter and $70 \mathrm{~cm}$ in depth. Each weekly sample consisted of 20 double strokes. These samples were taken by walking diagonally across the experimental area. The caught insect species were transferred to plastic sacs containing piece of cotton saturated with ether for anesthetizing the collected insects. The plastic sacs were well tied and taken to the laboratory and samples were examined by the aid of binocular microscope and the number of each species was recorded.

\section{Yellow sticky board trap}

The yellow sticky board trap consists of wooden board $(20 \times 30 \mathrm{~cm})$. This board was hanged on wooden rod with different heights to make the trap over plants by about $20 \mathrm{~cm}$ during the developmental period of plants. The sticky traps were changed weekly by new ones and the sticking insects were recognized, identified and counted.

\section{RESULTS AND DISCUSSION}

\section{Destructive and Beneficial Insect Species Associated with Certain Medicinal and Aromatic Plants}

Surveyed insect species inhabiting roselle, thyme and sweet basil plants are listed and arranged in Table 1 according to their orders and families concerning their scientific names, stage, feeding behaviour, site of occurrence and their host plant. Results revealed that 29 insect species belongs to 25 families and 10 orders were collected from the three medicinal and aromatic plants during the two seasons of the study. Destructive insects comprised 17 species belongs to 15 families and 8 orders. Predaceous insects compose 8 species of 6 families and 5 orders. Parasitoids were represented by only one species. Results also cleared that pollinators and visitors comprised 3 species belongs to 3 families and 2 orders. In general, it was observed that destructive species were more dominant than 
Table 1. List of insects associated with certain medicinal and aromatic plants at Awlad-Sakr district, Sharkia Governorate during two summer growing seasons 2015 and 2016

\begin{tabular}{|c|c|c|c|c|c|c|}
\hline Order & Family & Species & Stage & Feeding behaviour & $\begin{array}{c}\text { Site of } \\
\text { occurrence }\end{array}$ & Host plants \\
\hline \multirow[t]{3}{*}{ Homoptera } & Aphididae & Aphis gossypii Glover & Nymphs+ adults & Destructive & Leaves & Roselle, sweet basil and thyme \\
\hline & Aleyrodidae & Bemisia tabaci (Genn.) & Eggs + adults & Destructive & Leaves + fruits & Roselle, sweet basil and thyme \\
\hline & Cicadellidae & Empoasca decipiens (Paoli) & Nymphs+ adults & Destructive & Leaves & Roselle, sweet basil and thyme \\
\hline \multirow[t]{3}{*}{ Hemiptera } & Margarodidae & Icerya aegyptiaca (Douglas) & Nymphs + adults & Destructive & Leaves+ fruits & Roselle \\
\hline & Lygaeidae & Oxycarinus hyalinipennis (Costa) & Nymphs + adults & Destructive & Fruits & Roselle \\
\hline & Pentatomidae & Nezara viridula $\mathrm{L}$. & Nymphs + adults & Destructive & Leaves & Roselle, sweet basil and thyme \\
\hline \multirow[t]{4}{*}{ Lepidoptera } & Noctuidae & Spodoptera exigua (Hb.) & Larvae+ adults & Destructive & Leaves & Roselle \\
\hline & & Sesamia cretica Led. & Adults & Destructive & Leaves & Roselle \\
\hline & Gelechiidae & Sitotroga cerealella (Oliv.) & Larvae + adults & Destructive & Leaves & Roselle, sweet basil and thyme \\
\hline & Pyraustidae & Ostrinia nubilalis $\mathrm{Hbn}$. & Adults & Destructive & Leaves & Roselle and sweet basil \\
\hline \multirow[t]{5}{*}{ Diptera } & Culicidae & Culiseta longiareolata (Macq.) & Adults & Pollinator\& visitor & Leaves & Roselle, sweet basil and thyme \\
\hline & Muscidae & Musca domestica L. & Adults & Pollinator\& visitor & Leaves & Roselle, sweet basil and thyme \\
\hline & Syrphidae & Metasyrphus corollae (Fabr.) & Adults & Predator & Leaves & Roselle, sweet basil and thyme \\
\hline & & Egyptica legyptius & Adults & Predator & Leaves & Roselle, sweet basil and thyme \\
\hline & Agromyzidae & Liriomyza trifolii (Burg.) & Adults & Destructive & Leaves & Sweet basil \\
\hline \multirow[t]{4}{*}{ Hymenoptera } & Sphegidae & Philanthus abdelkader Luc. & Adults & Predator & Leaves & Roselle, sweet basil and thyme \\
\hline & Apidae & Apis mellifera $\mathrm{L}$. & Adults & Pollinator\& visitor & Leaves & Roselle, sweet basil and thyme \\
\hline & Formicidae & Monomorium pharaonis L. & Adults & Destructive & Leaves + fruits & Roselle and sweet basil \\
\hline & Braconidae & Chelonus ininatus $\mathrm{L}$. & Adults & Parasitoid & Leaves & Sweet basil \\
\hline Thysanoptera & Thripidae & Thrips tabaci Lind. & Nymphs + adults & Destructive & Leaves & Roselle, sweet basil and thyme \\
\hline \multirow[t]{3}{*}{ Coleoptera } & Curculionidae & Sitona lividipes Fab. & Adults & Destructive & Leaves & Roselle, sweet basil and thyme \\
\hline & Coccinellidae & Coccinella undecimpunctata $\mathrm{L}$. & Adults & Predator & Leaves & Roselle, sweet basil and thyme \\
\hline & & Scymnus punctillum Weise & Adults & Predator & Leaves & Sweet basil \\
\hline Odonata & Agrionidae & Ischnura senegalensis Ramb. & Adults & Predator & Leaves & Roselle and sweet basil \\
\hline \multirow[t]{2}{*}{ Orthoptera } & Acrididae & Aiolopus strepens (Latr.) & Adults & Destructive & Leaves & Sweet basil \\
\hline & & $\begin{array}{l}\text { Eyprepocnemis plorans } \\
\text { (Charp.) }\end{array}$ & Adults & Destructive & Leaves & Roselle, sweet basil and thyme \\
\hline Neuroptera & Chrysopidae & Chrysoperla carnea Steph. & Adults & Predator & Leaves & Sweet basil \\
\hline
\end{tabular}


beneficial species including predators, parasitoids, pollinators and visitors on the tested plants during the two growing seasons of the study.

Similar trends were found by Abd El-Moneim and Abd El-Wahab (2006) who recorded fourteen phytophagous insect species and six insect predators on roselle plants. These results agree partially with those of Ali et al. (2009), who found that the destructive insects were more dominant than beneficial insects on cumin plants, while diverse trend was recorded on anise and caraway plants at Abanoub district, Assiut Governorate, Egypt during 2007 and 2008 growing seasons.

\section{Survey and Relative Densities of Insect Pests}

\section{On roselle plants}

Obtained results in Table 2 revealed that thirteen insect species belongs to thirteen families and seven orders were surveyed on roselle plants. The most dominant species were arranged descendingly according to their relative densities as follows: Aphis gossypii Glover, Empoasca decipiens (Paoli), Bemisia tabaci (Genn.), Icerya aegyptiaca (Douglas) and Spodoptera exigua (Hb.). A. gossypii was the major insect pest species constituting 16.05 and $64.38 \%$ of the total number of pests during 2015 and 2016 growing seasons, respectively by general total percentage of $38.19 \%$, E. decipiens ranked second, representing 47.22 and $14.52 \%$ in the first and second seasons, alternatively by general total of $32.24 \%$, followed by $B$. tabaci which recorded 34.89 and $7.57 \%$ during the two successive growing seasons, consecutively. The general relative densities of I. aegyptiaca and $S$. exigua were 0.03 and $0 \%$ during the first season and 6.18 and $6.18 \%$ during the second one by general total percentage of 2.85 and $2.83 \%$, successively. Moreover, yellow sticky board trap proved to be the most effective method for collecting $E$. decipiens and $B$. tabaci, while plant sample was effective for estimating A. gossypii and I. aegyptiaca. The sweeping net was the pest method for collecting Cosmolyce baeticus and Nezara viridula L. Although Oxycarinus hyalinipennis (Costa) which was very injurious pest of the bolls showed relative densities of $0.36 \%$ in the first season and $0.60 \%$ in the second one.

The present results agree with the findings of Hammad and Mohsen (2000), Ismail (2001), Afsah (2005) and Ismail et al. (2010) who mentioned that $A$. gossypii, $T$. tabaci, $O$. hyalinipennis, E. decipiens and E. insulana were the most harmful insect pests on roselle plants.

\section{On thyme plants}

Nine insect species belongs to nine families and six orders were recorded on thyme plants as indicated in Table 3. The main caught insect species were B. tabaci, E. decipiens, A. gossypii and T. tabaci. B. tabaci was the most dominant species and comprised $52.10 \%$ of the total number of insect pests, followed by $E$. decipiens, $A$. gossypii and T. tabaci with values of 42, 2.85 and $2.65 \%$ in the first season of the study, respectively. Similar trends were found in the second season where the relative densities of $B$. tabaci was $48.86 \%$, followed by E. decipiens, A. gossypii and T. tabaci which recorded 42.70, 2.56 and $0 \%$, consecutively. Obtained results indicated that yellow sticky board traps were the most favourable technique for collecting B. tabaci, E. decipiens and T. tabaci, while plant samples were more effective for estimating aphids.

Similar results were obtained by Raich (1977), Legutowaska et al. (2005) and Mazhar et al. (2011) who recorded that thyme aphid, $A$. serpylli and $B$. tabaci were the main insect pest on thyme plants.

\section{On sweet basil plants}

As shown in Table 4, thirteen insect pest species belongs to twelve families and eight orders were recorded on sweet basil plants. The major insect species were $E$. decipiens, $B$. tabaci, C. baeticus, Aiolopus strepens (Latr.) and A. gossypii with densities of $60.79,29.09$, $3.12,2.83$ and $1.38 \%$ during the first season, while in the second season the relative densities of these 
Table 2. Total number of insect pests recorded on roselle plants, using plant sample, sweeping net and yellow sticky board trap at Awlad-Sakr district, Sharkia Governorate during the two summer growing seasons 2015 and 2016

\begin{tabular}{|c|c|c|c|c|c|c|c|c|c|c|c|c|}
\hline \multirow[t]{2}{*}{ Insect species } & \multicolumn{5}{|c|}{2015} & \multicolumn{5}{|c|}{2016} & \multicolumn{2}{|c|}{ General total } \\
\hline & PS & SN & YSBT & $\begin{array}{c}\text { Total } \\
\text { number }\end{array}$ & $\begin{array}{l}\text { RO } \\
(\%)\end{array}$ & PS & SN & YSBT & $\begin{array}{c}\text { Total } \\
\text { number }\end{array}$ & $\begin{array}{l}\text { RO } \\
(\%)\end{array}$ & Number & $\begin{array}{l}\text { RO } \\
(\%)\end{array}$ \\
\hline $\begin{array}{l}\text { Aphis gossypii Glover } \\
\text { (Homoptera: Aphididae) }\end{array}$ & 3987 & 0 & 0 & 3987 & 16.05 & 13514 & 0 & 0 & 13514 & 64.38 & 17501 & 38.19 \\
\hline $\begin{array}{l}\text { Empoasca decipiens (Paoli) } \\
\text { (Homoptera: Cicadeliidae) }\end{array}$ & 114 & 1 & 11613 & 11728 & 47.22 & 136 & 0 & 2911 & 3047 & 14.52 & 14775 & 32.24 \\
\hline $\begin{array}{l}\text { Bemisia tabaci (Genn.) } \\
\text { (Homoptera: Aleyrodidae) }\end{array}$ & 606 & 0 & 8059 & 8665 & 34.89 & 1314 & 0 & 274 & 1588 & 7.57 & 10253 & 22.37 \\
\hline $\begin{array}{l}\text { Icerya aegyptiaca (Douglas) } \\
\text { (Hemiptera: Margarodidae) }\end{array}$ & 7 & 0 & 0 & 7 & 0.03 & 1298 & 0 & 0 & 1298 & 6.18 & 1305 & 2.85 \\
\hline $\begin{array}{l}\text { Spodoptera exigua }(\mathrm{Hb} .) \\
\text { (Lepidoptera: Noctuidae) }\end{array}$ & 0 & 0 & 0 & 0 & 0 & 0 & 0 & 1298 & 1298 & 6.18 & 1298 & 2.83 \\
\hline $\begin{array}{l}\text { Thrips tabaci Lind. } \\
\text { (Thysanoptera: Thripidae) }\end{array}$ & 3 & 0 & 273 & 276 & 1.11 & 0 & 0 & 0 & 0 & 0 & 276 & 0.60 \\
\hline $\begin{array}{l}\text { Oxycarinus hyalinipennis (Costa) } \\
\text { (Hemiptera: Lygaeidae) }\end{array}$ & 90 & 0 & 0 & 90 & 0.36 & 125 & 0 & 0 & 125 & 0.60 & 215 & 0.47 \\
\hline $\begin{array}{l}\text { Cosmolyce baeticus L. } \\
\text { (Lepidoptera: Lycaenidae) }\end{array}$ & 4 & 22 & 5 & 31 & 0.12 & 0 & 37 & 9 & 46 & 0.22 & 77 & 0.17 \\
\hline $\begin{array}{l}\text { Nezera viridula } \mathrm{L} \text {. } \\
\text { (Hemiptera: Pentatomidae) }\end{array}$ & 5 & 12 & 6 & 23 & 0.09 & 1 & 14 & 6 & 21 & 0.10 & 44 & 0.10 \\
\hline $\begin{array}{l}\text { Sitona lividipes Fab. } \\
\text { (Coleoptera: Curculionidae) }\end{array}$ & 0 & 2 & 4 & 6 & 0.02 & 6 & 2 & 24 & 32 & 0.15 & 38 & 0.08 \\
\hline $\begin{array}{l}\text { Eyprepocnemis plorans (Charp.) } \\
\text { (Orthoptera: Acrididae) }\end{array}$ & 1 & 15 & 1 & 17 & 0.07 & 0 & 1 & 6 & 7 & 0.03 & 24 & 0.05 \\
\hline $\begin{array}{l}\text { Sesamia cretica Led. } \\
\text { (Lepidoptera: Noctuidae) }\end{array}$ & 0 & 0 & 0 & 0 & 0 & 0 & 1 & 13 & 14 & 0.07 & 14 & 0.03 \\
\hline $\begin{array}{l}\text { Monomorium pharaonis L. } \\
\text { (Hymenoptera: Formicidae ) }\end{array}$ & 7 & 0 & 0 & 7 & 0.03 & 0 & 0 & 0 & 0 & 0 & 7 & 0.02 \\
\hline General total & 4824 & 52 & 19961 & 24837 & 100 & 16394 & 55 & 4541 & 20990 & 100 & 45827 & 100 \\
\hline
\end{tabular}


Table 3. Total number of insect pests recorded on thyme plants, using plant sample, sweeping net and yellow sticky board trap at Awlad-Sakr district, Sharkia Governorate during the two summer growing seasons 2015 and 2016

\begin{tabular}{|c|c|c|c|c|c|c|c|c|c|c|c|c|}
\hline \multirow[t]{2}{*}{ Insect species } & \multicolumn{5}{|c|}{2015} & \multicolumn{5}{|c|}{2016} & \multicolumn{2}{|c|}{ General total } \\
\hline & PS & SN & YSBT & $\begin{array}{c}\text { Total } \\
\text { number }\end{array}$ & $\begin{array}{l}\text { RO } \\
\text { (\%) }\end{array}$ & PS & SN & YSBT & $\begin{array}{c}\text { Total } \\
\text { number }\end{array}$ & $\begin{array}{l}\text { RO } \\
(\%)\end{array}$ & Number & $\begin{array}{l}\text { RO } \\
\text { (\%) }\end{array}$ \\
\hline $\begin{array}{l}\text { Bemisia tabaci (Genn.) } \\
\text { (Homoptera: Aleyrodidae) }\end{array}$ & 95 & 12 & 3372 & 3479 & 52.10 & 26 & 0 & 871 & 897 & 48.86 & 4376 & 51.40 \\
\hline $\begin{array}{l}\text { Empoasca decipiens (Paoli) } \\
\text { (Homoptera: Cicadeliidae) }\end{array}$ & 6 & 22 & 2777 & 2805 & 42.00 & 12 & 3 & 769 & 784 & 42.70 & 3589 & 42.15 \\
\hline $\begin{array}{l}\text { Aphis gossypii Glover } \\
\text { (Homoptera: Aphididae) }\end{array}$ & 190 & 0 & 0 & 190 & 2.85 & 47 & 0 & 0 & 47 & 2.56 & 237 & 2.78 \\
\hline $\begin{array}{l}\text { Thrips tabaci Lind. } \\
\text { (Thysanoptera: Thripidae) }\end{array}$ & 0 & 0 & 177 & 177 & 2.65 & 0 & 0 & 0 & 0 & 0 & 177 & 2.08 \\
\hline $\begin{array}{l}\text { Cosmolyce baeticus } \mathbf{L} \text {. } \\
\text { (Lepidoptera: Lycaenidae) }\end{array}$ & 2 & 0 & 3 & 5 & 0.07 & 0 & 26 & 38 & 64 & 3.49 & 69 & 0.81 \\
\hline $\begin{array}{l}\text { Sitona lividipes Fab. } \\
\text { (Coleoptera:Curculionidae) }\end{array}$ & 3 & 1 & 11 & 15 & 0.22 & 4 & 2 & 13 & 19 & 1.03 & 34 & 0.40 \\
\hline $\begin{array}{l}\text { Nezera viridula } \mathrm{L} \text {. } \\
\text { (Hemiptera: Pentatomidae) }\end{array}$ & 0 & 0 & 2 & 2 & 0.03 & 0 & 17 & 8 & 25 & 1.36 & 27 & 0.32 \\
\hline $\begin{array}{l}\text { Sitotroga cerealella (Oliv.) } \\
\text { (Lepidoptera: Gelechiidae) }\end{array}$ & 0 & 0 & 4 & 4 & 0.06 & 0 & 0 & 0 & 0 & 0 & 4 & 0.05 \\
\hline $\begin{array}{l}\text { Eyprepocnemis plorans (Charp.) } \\
\text { (Orthoptera: Acrididae) }\end{array}$ & 1 & 0 & 0 & 1 & 0.01 & 0 & 0 & 0 & 0 & 0 & 1 & 0.01 \\
\hline General total & 297 & 35 & 6346 & 6678 & 100 & 89 & 48 & 1699 & 1836 & 100 & 8514 & 100 \\
\hline
\end{tabular}


Table 4. Total numbers of insect pests recorded on sweet basil plants, using plant sample, sweeping net and yellow sticky board trap at Awlad-Sakr district, Sharkia Governorate during the two summer growing seasons 2015 and 2016

\begin{tabular}{|c|c|c|c|c|c|c|c|c|c|c|c|c|}
\hline \multirow[t]{2}{*}{$\overline{\text { Insect species }}$} & \multicolumn{5}{|c|}{2015} & \multicolumn{5}{|c|}{2016} & \multicolumn{2}{|c|}{ General total } \\
\hline & PS & SN & YSBT & $\begin{array}{c}\text { Total } \\
\text { number }\end{array}$ & $\begin{array}{l}\text { RO } \\
(\%)\end{array}$ & PS & $\mathbf{S N}$ & YSBT & $\begin{array}{c}\text { Total } \\
\text { number }\end{array}$ & $\begin{array}{l}\text { RO } \\
(\%)\end{array}$ & Number & $\begin{array}{l}\text { RO } \\
(\%)\end{array}$ \\
\hline $\begin{array}{l}\text { Empoasca decipiens (Paoli) } \\
\text { (Homoptera: Cicadeliidae) }\end{array}$ & 43 & 29 & 7569 & 7641 & 60.79 & 17 & 0 & 2224 & 2241 & 59.47 & 9882 & 60.48 \\
\hline $\begin{array}{l}\text { Bemisia tabaci (Genn.) } \\
\text { (Homoptera: Aleyrodidae) }\end{array}$ & 167 & 0 & 3490 & 3657 & 29.09 & 49 & 0 & 1075 & 1124 & 29.83 & 4781 & 29.26 \\
\hline $\begin{array}{l}\text { Cosmolyce baeticus L. } \\
\text { (Lepidoptera: Lycaenidae) }\end{array}$ & 4 & 374 & 14 & 392 & 3.12 & 0 & 312 & 7 & 319 & 8.47 & 711 & 4.35 \\
\hline $\begin{array}{l}\text { Aiolopus strepens (Latr.) } \\
\text { (Orthoptera: Acrididae ) }\end{array}$ & 0 & 135 & 221 & 356 & 2.83 & 0 & 0 & 0 & 0 & 0 & 356 & 2.18 \\
\hline $\begin{array}{l}\text { Aphis gossypii Glover } \\
\text { (Homoptera: Aphididae) }\end{array}$ & 173 & 0 & 0 & 173 & 1.38 & 55 & 0 & 0 & 55 & 1.46 & 228 & 1.40 \\
\hline $\begin{array}{l}\text { Thrips tabaci Lind. } \\
\text { (Thysanoptera: Thripidae) }\end{array}$ & 0 & 0 & 189 & 189 & 1.50 & 0 & 0 & 0 & 0 & 0 & 189 & 1.16 \\
\hline $\begin{array}{l}\text { Nezera viridula } \mathbf{L} \text {. } \\
\text { (Hemiptera: Pentatomidae ) }\end{array}$ & 37 & 36 & 10 & 83 & 0.66 & 0 & 7 & 3 & 10 & 0.27 & 93 & 0.57 \\
\hline $\begin{array}{l}\text { Eyprepocnemis plorans (Charp.) } \\
\text { (Orthoptera: Acrididae) }\end{array}$ & 2 & 16 & 6 & 24 & 0.19 & 0 & 0 & 0 & 0 & 0 & 24 & 0.15 \\
\hline $\begin{array}{l}\text { Ostrinia nubilalis Hbn. } \\
\text { (Lepidoptera: Pyraustidae) }\end{array}$ & 0 & 10 & 5 & 15 & 0.12 & 0 & 0 & 0 & 0 & 0 & 15 & 0.09 \\
\hline $\begin{array}{l}\text { Liriomyza trifolii (Burg.) } \\
\text { (Diptera: Agromyzidae) }\end{array}$ & 13 & 0 & 0 & 13 & 0.10 & 0 & 0 & 0 & 0 & 0 & 13 & 0.08 \\
\hline $\begin{array}{l}\text { Sitotroga cerealella (Oliv.) } \\
\text { (Lepidoptera: Gelechiidae) }\end{array}$ & 0 & 3 & 1 & 4 & 0.03 & 0 & 0 & 0 & 0 & 0 & 4 & 0.02 \\
\hline $\begin{array}{l}\text { Monomorium pharaonis L. } \\
\text { (Hymenoptera: Formicidae ) }\end{array}$ & 4 & 0 & 0 & 4 & 0.03 & 0 & 0 & 0 & 0 & 0 & 4 & 0.02 \\
\hline General total & 443 & 607 & 11520 & 12570 & 100 & 124 & 321 & 3323 & 3768 & 100 & 16338 & 100 \\
\hline
\end{tabular}


insect pests were 59.47, 29.83, 8.47, 0 and $1.46 \%$, alternatively.

Such findings are in agreement with those of Banjo et al. (2006) and Lubiarz et al. (2013) who reported that the insects found on sweet basil plant were belonged to Homoptera, Diptera, Coleoptera, Orthoptera and Lepidoptera. Amaar (2010) carried out ecological studies on certain pests infesting sweet basil at North Sinai and Giza Governorates. The author recorded that the main piercing sucking insect species on sweet basil were A. gossypii, E. decipiens, T. tabaci, Tetranychus urticae Koch and Orius albidipennis.

\section{Survey and Relative Densities of Natural Enemies}

As shown in Table 5, five predaceous species belonging to five families and four orders were recorded on roselle plants. These species were arranged descendingly according to their relative densities as follows: Coccinella undecimpunctata L., Metasyrphus corollae (Fabr.), Ischnura senegalensis Ramb., Philanthus abdelkader Luc. and Polistes gallica L., they represented by $66.23,28.48,3.97,1.32$ and $0 \%$ in the first season and by $78.03,15.61,0.58,4.62$ and $1.16 \%$ in the second season, alternatively. It is worthy to mention that the arrangement of the three last predaceous insects in the second season somewhat varied as compared with the first one. On thyme plants three predaceous species belonging to three families and three orders were recorded. C. undecimpunctata was the most dominant insect predator with densities of 45.76 and $76.67 \%$ and it followed by $M$. corollae with relative densities of 54.24 and $20.00 \%$ during the two successive seasons, respectively. On sweet basil seven predaceous insect species belonging to five families and five orders and only one parasitoid species were recorded. The main caught natural enemies were C. undecimpunctata, Chelonus ininatus L., Egyptica legyptius and M. corollae with values of $26.19,25.60,33.93$ and $7.14 \%$ in the first season of the study, while the values were 38.04 , $32.61,0$ and $22.83 \%$ in the second one, successively.

Several predaceous species were recorded by many other researchers on medicinal and aromatic plants, e.g., Ali (1998) who found that C. undcimpunctata, S. syriacus, C. vulgaris and Sarcophaga sp. were associated with insect pests on mint and marjoram plants. Hammad and Mohsen (2000) recorded C. undcimpunctata, $S$. interruptus, O. albidipennis, O. laevigatus, $P$. alfierii and $M$. corollae as predatory insects on roselle plants. Ismail (2001) reported that C. carnea, C. undecimpunctata, S. interrptus, $P$. alfierii and $P$. gallica were the most important insect predaceous species on certain medicinal and aromatic plants. Afsah (2005) found that $C$. carnea was the main insect predator on roselle plants.

\section{Survey and Relative Densities of Pollinators and Visitors}

In Table 6 one pollinator species belong to 1 family and 1 order and two visitors belong to 2 families and 1 order were recorded on the three studied plants (roselle, thyme and sweet basil). According to their relative densities they represented on roselle plants as follows: Culiseta longiareolata (Macq), Musca domestica L. and Apis mellifera L. by $81.19,14.26$ and $4.55 \%$ in the first season as well as 95.05, 2.58 and $2.37 \%$, in the second one, respectively. On thyme plants the densities of $C$. longiareolate and $M$. domestica recorded 94.93 and $4.38 \%$ in the first seasons, while in the second one they were $81.63,12.11 \%$ followed by $A$. mellifera with low densities of 0.69 and $6.26 \%$, respectively. On sweet basil $C$. longireolate, $A$. mellifera and $M$. domestica were presented by $76.63,12.30$ and $11.06 \%$ in the first season as well as $75.61,16.29$ and $8.11 \%$ in the second season, respectively. 
Table 5. Survey and relative densities of some insect natural enemies on roselle, thyme and sweet basil plants, using plant sample, sweeping net and yellow sticky board trap at Awlad-Sakr district, Sharkia Governorate during 2015 and 2016 summer growing seasons

\begin{tabular}{|c|c|c|c|c|c|c|c|c|c|c|c|c|c|}
\hline \multirow[t]{2}{*}{ Host plant } & \multirow{2}{*}{$\begin{array}{l}\text { Parasitoid and predaceous } \\
\text { insect species }\end{array}$} & \multicolumn{5}{|c|}{2015} & \multicolumn{5}{|c|}{2016} & \multicolumn{2}{|c|}{ General total } \\
\hline & & $\mathbf{P S}$ & SN & YSBT & $\begin{array}{c}\text { Total } \\
\text { number }\end{array}$ & $\begin{array}{l}\text { RO } \\
(\%) \\
\end{array}$ & PS & $\mathbf{S N}$ & YSBT & $\begin{array}{c}\text { Total } \\
\text { number }\end{array}$ & $\begin{array}{l}\text { RO } \\
(\%) \\
\end{array}$ & Number & $\begin{array}{c}\text { RO } \\
\mid(\%) \\
\end{array}$ \\
\hline \multirow{7}{*}{ Roselle } & $\begin{array}{l}\text { Coccinella undecimpunctata L. } \\
\text { (Coleoptera: Coccinellidae) }\end{array}$ & 34 & 36 & 30 & 100 & 66.23 & 27 & 21 & 87 & 135 & 78.03 & 235 & 72.53 \\
\hline & $\begin{array}{l}\text { Metasyrphus corollae (Fabr.) } \\
\text { (Diptera: Syrphidae) }\end{array}$ & 1 & 23 & 19 & 43 & 28.48 & 5 & 8 & 14 & 27 & 15.61 & 70 & 21.60 \\
\hline & $\begin{array}{l}\text { Philanthus abdelkader Luc. } \\
\text { (Hymenoptera: Sphegidae) }\end{array}$ & 0 & 2 & 0 & 2 & 1.32 & 0 & 5 & 3 & 8 & 4.62 & 10 & 3.09 \\
\hline & $\begin{array}{l}\text { Ischnura senegalensis Ramb. } \\
\text { (Odonata: Agrionidae) }\end{array}$ & 0 & 6 & 0 & 6 & 3.97 & 0 & 1 & 0 & 1 & 0.58 & 7 & 2.16 \\
\hline & $\begin{array}{l}\text { Polistes gallica L. } \\
\text { (Hymenoptera: Vespidae) }\end{array}$ & 0 & 0 & 0 & 0 & 0 & 0 & 0 & 2 & 2 & 1.16 & 2 & 0.62 \\
\hline & General total & 35 & 67 & 49 & 151 & 100 & 32 & 35 & 106 & 173 & 100 & 324 & 100 \\
\hline & $\begin{array}{l}\text { Coccinella undecimpunctata L. } \\
\text { (Coleoptera: Coccinellidae) }\end{array}$ & 5 & 3 & 19 & 27 & 45.76 & 0 & 6 & 17 & 23 & 76.67 & 50 & 56.18 \\
\hline \multirow[t]{5}{*}{ Thyme } & $\begin{array}{l}\text { Metasyrphus corollae (Fabr.) } \\
\text { (Diptera: Syrphidae) }\end{array}$ & 4 & 4 & 24 & 32 & 54.24 & 1 & 3 & 2 & 6 & 20.00 & 38 & 42.70 \\
\hline & $\begin{array}{l}\text { Philanthus abdelkader Luc. } \\
\text { (Hymenoptera: Sphegidae) }\end{array}$ & 0 & 0 & 0 & 0 & 0 & 0 & 0 & 1 & 1 & 3.33 & 1 & 1.12 \\
\hline & $\begin{array}{l}\text { Chelonus ininatus L. } \\
\text { (Hymenoptera: Braconidae) }\end{array}$ & 0 & 0 & 43 & 43 & 25.60 & 1 & 2 & 27 & 30 & 32.61 & 73 & 28.08 \\
\hline & $\begin{array}{l}\text { Egyptica legyptius } \\
\text { (Diptera: Syrphidae) }\end{array}$ & 0 & 49 & 8 & 57 & 33.93 & 0 & 0 & 0 & 0 & 0 & 57 & 21.92 \\
\hline & $\begin{array}{l}\text { Metasyrphus corollae (Fabr.) } \\
\text { (Diptera: Syrphidae) }\end{array}$ & 3 & 4 & 5 & 12 & 7.14 & 3 & 8 & 10 & 21 & 22.83 & 33 & 12.69 \\
\hline \multirow{5}{*}{ Sweet basil } & $\begin{array}{l}\text { Chrysoperla carnea Steph. } \\
\text { (Neuroptera: Chrysopidae) }\end{array}$ & 0 & 0 & 0 & 0 & 0 & 1 & 5 & 0 & 6 & 6.52 & 6 & 2.31 \\
\hline & $\begin{array}{l}\text { Philanthus abdelkader Luc. } \\
\text { (Hymenoptera: Sphegidae) }\end{array}$ & 0 & 4 & 1 & 5 & 2.98 & 0 & 0 & 0 & 0 & 0 & 5 & 1.92 \\
\hline & $\begin{array}{l}\text { Ischnura senegalensis Ramb. } \\
\text { (Odonata: Agrionidae) }\end{array}$ & 0 & 3 & 1 & 4 & 2.38 & 0 & 0 & 0 & 0 & 0 & 4 & 1.54 \\
\hline & $\begin{array}{l}\text { Scymnus punctillum Weise } \\
\text { (Coleoptera: Coccinellidae) }\end{array}$ & 0 & 2 & 1 & 3 & 1.79 & 0 & 0 & 0 & 0 & 0 & 3 & 1.15 \\
\hline & General total & 13 & 74 & 81 & 168 & 100 & 8 & 22 & 62 & 92 & 100 & 260 & 100 \\
\hline
\end{tabular}


Table 6. Survey and relative densities of pollinators and visitors on roselle, thyme and sweet basil plants, using plant sample, sweeping net and yellow sticky board trap at Awlad-Sakr district, Sharkia Governorate during 2015 and 2016 growing seasons

\begin{tabular}{|c|c|c|c|c|c|c|c|c|c|c|c|c|c|}
\hline \multirow[t]{2}{*}{ Host plant } & \multirow{2}{*}{$\begin{array}{l}\text { Pollinator and visitor } \\
\text { insect species }\end{array}$} & \multicolumn{5}{|c|}{2015} & \multicolumn{5}{|c|}{2016} & \multicolumn{2}{|c|}{ General total } \\
\hline & & PS & SN & YSBT & $\begin{array}{c}\text { Total } \\
\text { number }\end{array}$ & $\begin{array}{l}\text { RO } \\
(\%)\end{array}$ & PS & $\mathbf{S N}$ & YSBT & $\begin{array}{c}\text { Total } \\
\text { number }\end{array}$ & $\begin{array}{l}\text { RO } \\
\text { (\%) }\end{array}$ & Number & $\begin{array}{l}\text { RO } \\
(\%)\end{array}$ \\
\hline \multirow{4}{*}{ Roselle } & $\begin{array}{l}\text { Culiseta longiareolata (Macq.) } \\
\text { (Diptera: Culicidae) }\end{array}$ & 74 & 42 & 2987 & 3103 & 81.19 & 77 & 20 & 4507 & 4604 & 95.05 & 7707 & 88.93 \\
\hline & $\begin{array}{l}\text { Musca domestica L. } \\
\text { (Diptera: Muscidae) }\end{array}$ & 30 & 104 & 411 & 545 & 14.26 & 4 & 49 & 72 & 125 & 2.58 & 670 & 7.73 \\
\hline & $\begin{array}{l}\text { Apis mellifera L. } \\
\text { (Hymenoptera: Apidae) }\end{array}$ & 1 & 148 & 25 & 174 & 4.55 & 0 & 83 & 32 & 115 & 2.37 & 289 & 3.33 \\
\hline & General total & 105 & 294 & 3423 & 3822 & 100 & 81 & 152 & 4611 & 4844 & 100 & 8666 & 100 \\
\hline \multirow{4}{*}{ Thyme } & $\begin{array}{l}\text { Culiseta longiareolata (Macq.) } \\
\text { (Diptera: Culicidae) }\end{array}$ & 20 & 14 & 3131 & 3165 & 94.93 & 1 & 27 & 363 & 391 & 81.63 & 3556 & 93.26 \\
\hline & $\begin{array}{l}\text { Musca domestica L. } \\
\text { (Diptera: Muscidae) }\end{array}$ & 4 & 15 & 127 & 146 & 4.38 & 0 & 10 & 48 & 58 & 12.11 & 204 & 5.35 \\
\hline & $\begin{array}{l}\text { Apis mellifera L. } \\
\text { (Hymenoptera: Apidae) }\end{array}$ & 0 & 13 & 10 & 23 & 0.69 & 0 & 7 & 23 & 30 & 6.26 & 53 & 1.39 \\
\hline & General total & 24 & 42 & 3268 & 3334 & 100 & 1 & 44 & 434 & 479 & 100 & 3813 & 100 \\
\hline \multirow{4}{*}{ Sweet basil } & $\begin{array}{l}\text { Culiseta longiareolata (Macq.) } \\
\text { (Diptera: Culicidae) }\end{array}$ & 36 & 21 & 2478 & 2535 & 76.63 & 5 & 58 & 1028 & 1091 & 75.61 & 3626 & 76.32 \\
\hline & $\begin{array}{l}\text { Apis mellifera L. } \\
\text { (Hymenoptera: Apidae) }\end{array}$ & 22 & 348 & 37 & 407 & 12.30 & 0 & 212 & 23 & 235 & 16.29 & 642 & 13.51 \\
\hline & $\begin{array}{l}\text { Musca domestica } \mathrm{L} \text {. } \\
\text { (Diptera: Muscidae) }\end{array}$ & 13 & 51 & 302 & 366 & 11.06 & 7 & 36 & 74 & 117 & 8.11 & 483 & 10.17 \\
\hline & General total & 71 & 420 & 2817 & 3308 & 100 & 12 & 306 & 1125 & 1443 & 100 & 4751 & 100 \\
\hline
\end{tabular}




\section{REFERENCES}

Abd El-Megid, J.E. (2007). Main insect pests of mint and their associated natural enemies at Hehia district, Sharkia Governorate. Zagazig J. Agric. Res., 34 (3): 513-540.

Abd El-Moneim, A.S.M. and T.E. Abd ElWahab (2006). Insect pests and predators inhabiting roselle plants, Hibiscus sabdariffa L., a medicinal plant in Egypt. Arch. Phytopathol. and Plant Protect., 39 (1): 2532.

Abd El-Moneim, A.S.M., T.E. Abd El-Wahab and N.A. Farag (2011). Prevailing insects in roselle plants, Hibiscus sabdariffa L. and their efficieny on pollination. Arch. Phytopathol. and Plant Protect., 44 (3): 242252.

Afsah, A.F.E. (2005). Studies on some pests attacking certain medicinal and aromatic plants. Ph.D. Thesis, Fac. Agric., Zagazig Univ., Egypt.

Ahmad, A.M.T. (1990). Studies on some insect pests infesting certain medicinal plants. Ph.D. Thesis, Al-Azahar Univ., Egypt.

Ali, A.G. (1998) Ecological and control studies on certain pests infesting medicinal and aromatic plants. Ph.D. Thesis, Fac. Agric., Assiut Univ., Egypt.

Ali, A.G., M.Z. Embarak and A.E. Ahmed (2009). Specific composition and seasonal fluctuation of destructive and beneficinal insect species inhabiting three medicinal plants in Assiut Governorate. Ass. Univ. Bull. Environ. Res., 12 (2): 77-87.

Amaar, M.I. (2010). Ecological studies on certian pests infesting medicinal plants family Labiatae. M.Sc. Thesis, Fac. Agric., Ain Shams Univ., Egypt.

Banjo, A.D., O.A. Lawal and S.A. Aina (2006). Insect diversity of two medicinal labiate in southwestern Nigeria. J. Entomol., 3 (4): 248 -304 .
Hammad, K.A.A. and A.M. Mohsen (2000). Insects infesting roselle and their associated natural enemies in newly reclaimed sandy land. Egypt. J. Appl. Sci., 15 (7): 618-642.

Ismail, H.A., I.M. Kelany, Jasmin E. Abd ElMegid, and M.M.A. Ibraheem (2010). Survey and relative densities of insect pests and their predators associated with mint, roselle and marjoram at Abo-Kabir district, Sharkia Governorate. Zagazig. J. Agric. Res., 37 (5): 1193-1210.

Ismail, H.A., S.Sh.M. Gamila and O.I.M. Hegab (2016). Ecological studies on some insect pests infesting rosemary plants and their associated predators at Abo-Kabir district, Sharkia Governorate. J. Plant Prot. and Path., Mansoura Univ., 7 (9): 587- 592.

Ismail, O.M.N. (2001). Studies on some insects attacking aromatic and medicinal plants. M.Sc. Thesis, Fac. Agric., Cairo Univ., Egypt.

Legutowaska, H., I. Zawirska and M. Setniewska (2005). Thrips (Thysanoptera) occuring in selected herbal plants. Progress in Pl. Prot., 45 (2): 850 - 852.

Lubiarz, M., W. Goszczynski and E. Cichocka (2013). Invertebrates inhabiting culinary herbs grown under cover. J. Pl. Prod. Res., 53 (4): 333-337.

Mazhar, N.R., S.E. Sadeghi and F. Adel (2011). Pests and diseases associated with Thymus species in Hamadan province. Iranian $\mathrm{J}$. Forest and Rang Prot. Res., 4 (1): 26-36.

Raich, K.V. (1977). Thymus vulgaris aureus (Family: Labiatae), a new host plant of the cabbage web-worm, Crocidolomia binotalis Zell. (Pyralididae: Lepidoptera). Indian J. Entomol., 37 (3): 313-314.

Ramadan, M.A.M.E. (1998). Ecological and biological studies on certain insects infesting medicinal and aromatic plants in Egypt. Ph.D. Thesis, Fac. Agric., Cairo Univ., Egypt. 


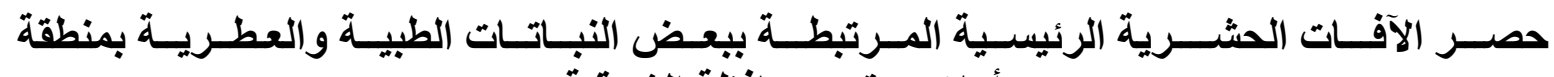
أولاد صقر - محافظة الثرقية

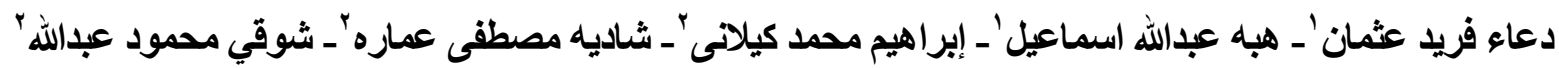

$$
\begin{aligned}
& \text { ا ـ معهد بحوث وقاية النباتات ـ الدقي - جيزة ـ مصر - مبر }
\end{aligned}
$$

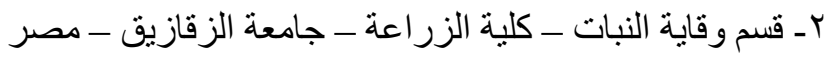

أُجريت هذه الدراسة بهدف حصر الآفات الحشرية الرئيسية التي تصيب نباتات الكركديه، الزعتر و الريحان وائرة وكذلك أهم

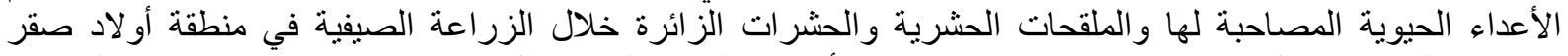

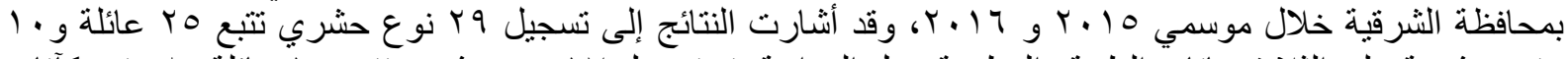

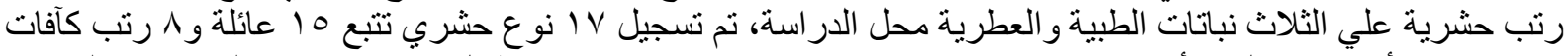

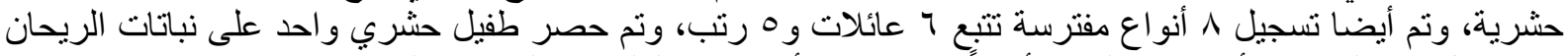

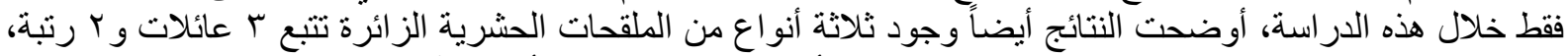

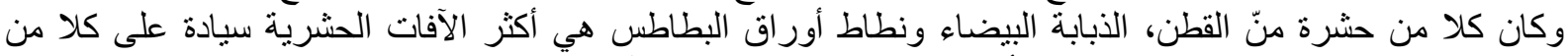

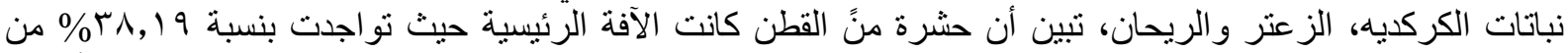

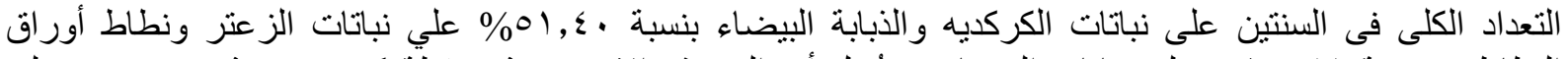

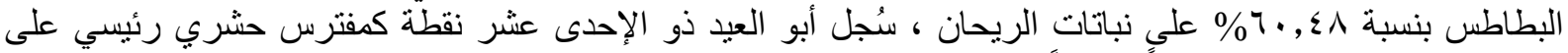

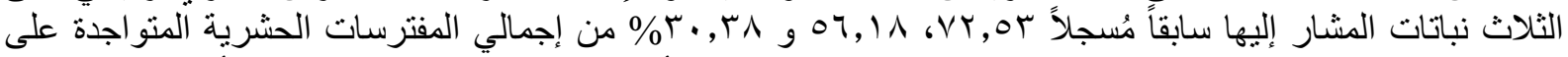

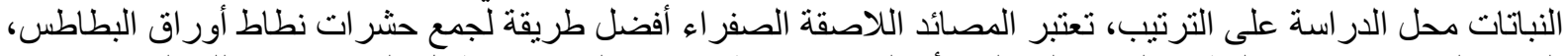

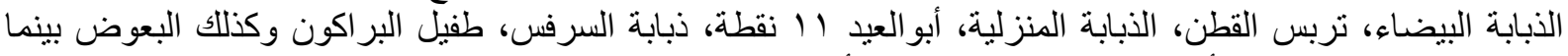

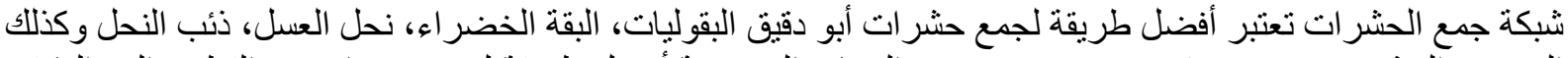
المفترس الحشري Egyptica legyptius، وتعتبر العينات الخضرية أفضل طريقة لجئة لجمع حسرات من القطن و البق الدقيقي المصري. 